\title{
Assessing the species diversity in non-conservation areas: The first systematic camera trapping survey in the Batang Angkola landscape, North Sumatra, Indonesia
}

\author{
Anton Ario ${ }^{1}$, Sarmaidah Damanik ${ }^{1}$, Ahsan Rabbani ${ }^{1}$, Berto Naibaho ${ }^{1}$, Abdul Rojak Hasibuan ${ }^{1}$, Sahiruddin \\ Hasibuan $^{1}$, M. Arif Hasibuan ${ }^{2}$, and Ambet P. Harianja ${ }^{3}$
}

\author{
${ }^{1}$ Conservation International Indonesia, Jl. PA. Sitompul, Komplek DPR Blok A1 No. 999, Wek VI, Padang Sidempuan, \\ North Sumatra 22724, Indonesia \\ ${ }^{2}$ Forest Management Unit X Padang Sedempuan, Jl. Kenanga No. 68, Padang Sidempuan, North Sumatra 22725, \\ Indonesia \\ ${ }^{3}$ Natural Resources Conservation Agency of North Sumatra, Jl. S.M. Raja No. 14 Km. 5.5, Medan, North Sumatra, \\ Indonesia
}

Corresponding author: Anton Ario, aario@conservation.org

\begin{abstract}
Assessing the species diversity in non-conservation areas is crucial to understanding for conservation interventions and management. We used camera trapping to investigate the species diversity in the Batang Angkola Landscape, North Sumatra. The study on species diversity in the area was conducted from February to June 2020. The aim of this study was to assess the species diversity in Batang Angkola Landscape as a reference for the improvement of the management and policy with a special interest in proving the existence of wildlife species in the landscape. We compiled a species diversity, richness and evenness data which were analysed by Shannon Wiener. Based on 1,283 photographs at 60 camera traps stations during 2,923 trap days, we identified 27 different species (24 species were terrestrial mammals, 2 bird species, and 1 species was reptile), including five classified as threatened according to the IUCN. Based on the calculation of the Relative Abundance Indices for each species per 100 trap days, pig-tailed macaque had the highest RAI (3.63 photographed/100 trap days), followed by wild boar and muntjac deer were (1.33 and 1.27 photographed/100 traps days respectively). Based on Shannon Weiner's analysis shows the analysis of species diversity $(\mathrm{H})$, which showed that in the northern and southern areas it were moderate category (2.40 and 2.45 respectively). The level of evenness between north and south areas shows high evenness $(0.77$ and 0.79 respectively). Meanwhile, the level of species richness between north and south shows moderate to high levels in the two areas (3.95 and 4.42 respectively). Our findings suggest that Batang Angkola Landscape supports a high species richness. Continued survey efforts need to be combined with detailed ecological data collection and effective management in the region.
\end{abstract}

\begin{abstract}
ABSTRAK
Menilai keanekaragaman spesies di kawasan non-konservasi sangat penting untuk memahami upaya pengelolaan dan intervensi konservasi. Kami menggunakan camera trap untuk menyelidiki keanekaragaman spesies di Bentang Alam Batang Angkola di Sumatera Utara. Kajian keanekaragaman jenis di kawasan ini dilakukan selama 5 bulan dari Februari hingga Juni 2020. Tujuan penelitian ini adalah untuk mengkaji keanekaragaman jenis di bentang alam Batang Angkola sebagai acuan perbaikan tata kelola dan kebijakan, spesifik pada membuktikan keberadaan spesies satwa liar. Data keanekaragaman spesies, kekayaan dan kemerataan yang kami kumpulkan, dianalisis dengan Shannon wiener. Berdasarkan 1.283 foto di 60 stasiun perangkap kamera selama 2.923 hari rekam, kami mengidentifikasi 27 spesies berbeda (24 spesies mamalia darat, 2 spesies burung, dan 1 spesies reptil), termasuk lima jenis yang diklasifikasikan sebagai satwa terancam menurut IUCN. Berdasarkan perhitungan Indeks Kelimpahan Relatif untuk setiap spesies per 100 hari rekam, beruk memiliki RAI tertinggi (3,63 foto / 100 hari rekam), disusul babi hutan dan kijang (masing-masing 1,33 dan 1,27 foto / 100 hari rekam). Berdasarkan analisis Shannon-Weiner untuk keanekaragaman jenis $(\mathrm{H})$ menunjukkan bahwa di wilayah utara dan selatan dalam kategori sedang (masing-masing 2,40 dan 2,45). Tingkat kemerataan antara wilayah utara dan selatan menunjukkan tingkat kategori kemerataan yang tinggi (masing-masing 0,77 dan 0,79). Tingkat kekayaan spesies antara utara dan selatan menunjukkan kategori tingkat sedang hingga tinggi di kedua wilayah tersebut (masing-masing 3,95 dan 4,42). Temuan kami menunjukkan bahwa Bentang Alam Batang Angkola mendukung kekayaan spesies yang tinggi. Upaya survey lanjutan perlu digabungkan dengan pengumpulan data ekologi yang terperinci dan pengelolaan yang efektif di wilayah tersebut.
\end{abstract}

Keywords: batang angkola, camera trap, hutan produksi, hutan lindung, keragaman jenis.

\section{INTRODUCTION}

Sumatra is part of Southeast Asia's Sundaland biodiversity hotspot, recognized as one of the 25 richest

Submitted 09 September 2020; Accepted 21 September 2020. and most threatened reservoirs of plant and animal life on Earth (Perbatakusuma et al., 2010). The important Sumatra ecosystems which consist of freshwater swamps, lowland rainforest, montane rainforest, peat 
swamps, and tropical pine forest (Whitten et al. 2000; Wikramanayake et al., 2002), are home to more than 10,000 plant species, 210 mammal species are uniques, including the Sumatran orangutan (Pongo abelli), Sumatran elephant (Elephas maximus sumatrensis), Sumatran rhinoceros (Dicerorhinus sumatrensis) and Sumatran tiger (Panthera tigris sumatrae) (Perbatakusuma et al., 2010).

The impact of anthropogenic activities on land use worldwide includes accelerated deforestation and habitat fragmentation caused by conversion for other land use purposes and infrastructure developments, further contributing to declining local biodiversity (Newbold et al., 2015). Much of biodiversity in Sumatra is at risk due to vast areas of primary forest (up to 0.38 million hectares per year) being cleared for timber products or converted to other land uses, such as agriculture (e.g. coffee, rubber), oil palm, and Acacia mangium tree plantations (Margono et al., 2012; Sodhi et al., 2004; Stibig et al., 2014). These habitat loss have been linked to population declines in many mammals, including flagship species such as Sumatran tiger, Sumatran rhinoceros, and Asian elephant (Kinnaird et al., 2003; Linkie et al., 2003; Hedges et al., 2005; Isnan et al., 2006).

Traditionally, wildlife conservation often focuses on conservation areas, management of which forms the core of most countries' conservation efforts. In many cases, land outside protected areas also have conservation values. Whilst this is rarely of the quality found in protected areas, using the conservation potential of unprotected lands can help overcome many of the shortfalls of the protected area system. For certain species, especially those which naturally occur at very low population densities, this support could tip the balance from extinction to survival (Maddox et al., 2007). Despite the potential value in alleviating the restrictions of protected areas, biodiversity on unprotected lands is under-researched and poorly understood scientifically (Shafer, 1999).

Wildlife diversities are known to exist in several nature reserves, wildlife reserves, national parks, and protected forests, including in Batang Gadis National Park (BGNP) and Batang Toru Protected Forest (BTPF) in North Sumatra. The actual species distribution and number of individuals of wildlife in Northern Sumatra is still being investigated, and there are only few scientific data sets that have been systematically collected, especially within the Batang Angkola landscape (BAL). Batang Angkola is one of the key biodiversity areas in North Sumatra, connecting three other critical ecosystems, namely BGNP, BTPF and Barumun Wildlife Reserve (BWR).

Conservation International Indonesia (CI Indonesia) has worked in North Sumatra since 2002 to support the protection and connection of these biodiversity hotspots, which are currently under threat from the agriculture sectors. In early 2019, CI Indonesia and the Forestry Management Unit (FMU) (under local government management) recorded tiger scats and footprints in the forest from the first ever biological surveys in BAL (4,800 hectares [ha]). This area was selected because there had never been scientific research into the presence of the wildlife here. Moreover, it was suspected that BAL was the trajectory of Sumatran tigers moving between BGNP and BWR.

Protecting wildlife and their habitat requires a landscape approach to ensure that habitat connections are maintained. To maintain and improve the biological connectivity in the landscapes between BGNP and BWR is crucial for wide-ranging species such as the Sumatran tiger. Therefore, the aim of this study is to assess the species diversity in BAL as a reference for the improvement of the management and policy for the landscape, with a special interest in proving the existence of wildlife species in the non-conservation area.

\section{METHODS}

\section{Study Area}

Study was conducted in Batang Angkola Landscape from February to June 2020. The study site was located at $01^{\circ} 18^{\prime} 28.78^{\prime \prime} \mathrm{N}$ and $99^{\circ} 14^{\prime} 34.51^{\prime \prime} \mathrm{E}$, at altitudes of 90 to $1,422 \mathrm{~m}$ above sea level (Figure 1). The area consists of protected forest and production forest, including concession area under managed by Forest Management Unit of North Sumatra. The study was conducted in two main areas in Batang Angkola (the north and south areas) that cover a total of 47,518 ha. The north area was surveyed from February 5 to March 29, 2020, covering 23,200 ha and south area was surveyed from May 17 to June 25, 2020, covering 24,318 ha. This area directly connect to Batang Gadis National Park, which is confirmed home-range for Sumatran tiger.

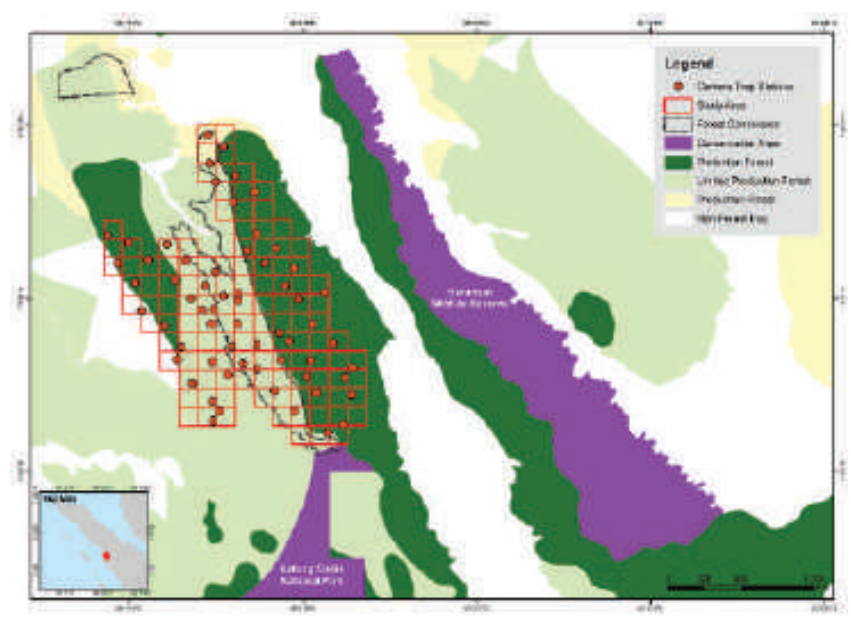

Figure 1. Map of study area that cover a total of 47,518 ha, most of it is protection and production forest, including a concession area (with total of 15,000 ha). The map also shown connectivity of critical landscape in North Sumatra. 


\section{Data Collection}

We used 30 camera traps (Cuddeback $X$ Change Color Model 1279) for this study. A single of 30 camera traps at 60 trapping stations deployed on the study area, encompassing an area of approx. 47,518 ha. Ideally such cameras should be set up in pairs to allow both sides of recognizable animals to be photographed (Karanth and Nichols, 2002). However, because we were limited by our number of camera traps, all camera traps were deployed with a single camera in each location, and we separated the survey to become two sections, the north and south sections.

The cameras were set in the forest within in a grid of four $\mathrm{km}^{2}$ across elevational and vegetation type gradients. We selected areas that had applied alongside camera trap standardized design so that the results could be analyzed according to the latest analysis. We installed 30 camera traps in 30 stations in each section. In first section, we installed 30 camera traps in north area. After 60 days operated in the north area, we pick up them, checked camera conditions, replaced batteries and memory cards. We moved them to south sections in same number camera traps in other 30 stations in south area. After 60 days operated in the south area, we pick up them and all results were entered into database for each sampling areas.

\section{Data Analyses}

For sampling efforts, we analyze used a Relative Abundance Indices (RAI) measure for each captured species. RAI represents the number of independent pictures for each species per 100 trap days. We followed the definition of independent pictures as (1) consecutive photographs of different individuals of the same or different species, (2) consecutive photographs of individuals of the same species taken more than 0.5 hours apart, (3) non-consecutive photos of individuals of the same species (O’Brien et al., 2003).
RAI was determined using encounter rates that give basic ordinal scales of abundance. It was calculated as:

$$
\mathbf{R A I}=\mathbf{S F} / \mathbf{T D} * 100
$$

Where: RAI $=$ Relative Abundance Index; $\mathrm{SF}=$ number of species photograph, $\mathrm{TD}=$ trap days

We used Shannon-Weiner diversity index $\mathrm{H}$ (Shannon, 1948), an index indicating the diversity of species photograph from all camera traps for each day of the study in each section sampling areas. Species richness and abundance were defined as the total number of species and total number of contacts respectively (Table 1). We followed Kiros et al., (2018) for Shannon-Weiner diversity index $\left(\mathrm{H}^{\prime}\right)$ was used to analyse species diversity was calculated as:

$$
\mathrm{H}^{\prime}=-\sum_{\mathrm{i}=1}^{\mathrm{s}}\left(\frac{\mathrm{ni}}{\mathrm{N}}\right) \times \ln \left(\frac{\mathrm{ni}}{\mathrm{N}}\right)
$$

Where $\mathrm{H}^{\prime}$ = Shannon-Weiner diversity index; pi = proportion of the photograph species from species i.;

Evenness index $\left(J^{\prime}\right)$ was calculated by following the equation.

$$
\mathrm{J}^{\prime}=\frac{\mathrm{H}^{\prime}}{\ln \mathrm{S}}
$$

Where: $\mathrm{H}^{\prime}=$ Shannon Weiner diversity index and $\mathrm{S}=$ number of species.

Richness index (D) was calculated by the following equation

$$
\mathrm{D}=\frac{\mathrm{S}-1}{\ln \mathrm{N}}
$$

Where: $\mathrm{D}=$ Richness index, $\mathrm{S}=$ Total number of species and $\mathrm{N}=$ Total number of individuals.

Table 1. Shannon-Weiner Index criteria's.

\begin{tabular}{l|l|l}
\hline \multicolumn{1}{c|}{$\begin{array}{c}\text { Criteria for index of species } \\
\text { diversity }\left(\mathbf{H}^{\prime}\right)\end{array}$} & Criteria for Evenness index $\left(\mathrm{J}^{\prime}\right)$ & Criteria for Richness index (D) \\
\hline $\begin{array}{l}\mathrm{H}^{\prime}<1 \text { a low level of species } \\
\text { diversity, }\end{array}$ & $\mathrm{J}^{\prime} \leq 0.4$ low evenness & $\begin{array}{l}\mathrm{D}<1.5 \text { a low level of species } \\
\text { richness }\end{array}$ \\
\hline $\begin{array}{l}1<\mathrm{H}^{\prime}<3 \text { a moderate level of } \\
\text { species diversity }\end{array}$ & $0.4<\mathrm{J}^{\prime}<0.6$ moderate evenness & $\begin{array}{l}1.5>\mathrm{D}>4 \text { a moderate level of } \\
\text { species richness }\end{array}$ \\
\hline $\begin{array}{l}\mathrm{H}^{\prime}>3 \text { indicates a high level of } \\
\text { species diversity }\end{array}$ & $\mathrm{J}^{\prime} \geq 0.6$ high evenness & $\begin{array}{l}\mathrm{D}>4 \text { a high level of species } \\
\text { richness }\end{array}$ \\
\hline
\end{tabular}

\section{RESULTS AND DISGUSSION}

\section{Capture Rates}

There were 60 stations that had been camera trap installed in the field during this study. However, there were only 58 stations where camera traps working properly, while the others 2 stations did not get any pictures, caused by cameras error. Of these 58 stations, the results reveal the significance and diversity of the Batang Angkola Landscape. A total of 1,283 animal photographs (341 independent photographs) of at least 27 different species (24 species were terrestrial mammals, 2 bird species, and 1 species was reptile) were recorded from a total of 2,923 trap days. Carbone et al., (2001) suggested a minimum of 1,000 trap days 
were required to obtain comprehensive information on diversity and population estimation of certain cryptic mammalian species. Example images for every species captured in the survey are provided in Appendix1.

Based on results during period camera trapping, notable results from this period of surveying include two Critically Endangered species (Sumatran tiger and Sunda pangolin Manis javanica), three endangered species (Sumatran clouded leopard Neofelis diardi, Malay tapir Tapirus indicus, and Black Sumatran langur Presbytis sumatrana), five vulnerable (Malay sun bear
Helarctos malayanus, Sambar deer Rusa unicolor, Sumatran serow Capricornis sumatraensis, Binturong Arctictis binturong, Pig-tailed macaque Macaca nemestrina), three species endemic to Sumatra (Sumatran tiger, Sumatran clouded leopard, Black Sumatran langur) and five of the six species of Sumatran wild cats (Sumatran tiger, Sumatran clouded leopard, Asiatic golden cat, Marbled cat, and Leopard cat). See Table 2 contains the list of identified species and IUCN Red List classifications.

Table 2. Identified species during the Camera Trapping at Batang Angkola Landscape.

\begin{tabular}{lll}
\hline Species & Common name & IUCN Relist Status \\
\hline Panthera tigris sumatrae & Sumatran tiger & Critically Endangered \\
Neofelis diardii & Sumatran clouded leopard & Endangered \\
Catopuma temminckii & Asiatic golden cat & Near threatened \\
Pardofelis marmorata & Marbled cat & Near threatened \\
Prionailurus bengalensis & Leopard cat & Least concern \\
Helarctos malayanus & Sun bear & Vulnerable \\
Hemigalus derbyanus & Banded palm civet & Near threatened \\
Herpestes brachyurus & Short-tailed mongoose & Least concern \\
Paguma larvata & Masked palm civet & Least concern \\
Martes flavigula & Yellow-throated marten & Least concern \\
Herpestes semitorquatus & Collared mongoose & Least concern \\
Arctictis binturong & Binturong & Vulnerable \\
Tapirus Indicus & Malay tapir & Endangered \\
Rusa unicolor & Sambar deer & Vulnerable \\
Sus scrofa & Wild boar & Least concern \\
Tragulus kanchil & Lesser mouse deer & Least concern \\
Muntiacus muntjak & Muntjak & Least concern \\
Capricornis sumatraensis & Sumatran serow & Vulnerable \\
Presbytis sumatrana & Black sumatran langur & Endangered \\
Macaca nemestrina & Pig-tailed macaque & Vulnerable \\
Macaca fascicularis & Long-tailed macaque & Least concern \\
Manis javanica & Sunda pangolin & Critically Endangered \\
Rattus tiomanicus & Malayan field rat & Least concern \\
Hystrix brachyuran & Malayan porcupine & Least concern \\
Argusianus argus & Great argus & Near threatened \\
Chalcophaps indica & Emerald dove & Least concern \\
Varanus salvator & Common water monitor & Least concern \\
\hline & &
\end{tabular}

Based on the calculation of the relative abundance index in the two areas, the values obtained for each species, where the Pig-tailed macaque, Wild boar, and Barking deer had the highest RAI (3.63, 1.33, and 1.27 photographed/100 trap days, respectively) compared to other species. Whilst the Sumatran tiger, as the top predators in the region, placed at 18th rank with a RAI value of 0.07 . Based on trophic level (based on the type of food) which is divided into three categories i.e. herbivores, carnivores and omnivores, the relative abundance of herbivores has a high value. Therefore, the pyramid of food web will be formed properly and the balance of the ecosystem in the research location will be occurred Huda et al., (2020). This is in line with the study of Huda et al., (2020) which the Sumatran tiger in Batutegi Protected Forest, has the position of 
15th rank of RAI with a value of 0.13 , and Santosa et al., (2008) which obtained 14 species of herbivores, five species of carnivores, and three species of omnivores in Tanjung Puting National Park, Central Kalimantan.Indices for each species per 100 trap days, Pig-tailed macaque had the highest RAI (3.63 photographed /100 trap days), followed by Wild boar and Muntjac were (1.33 and 1.27 photographed/100 traps days respectively) (Figure 2).

Camera traps, which have increasingly been used in wildlife studies (Wemmer et al., 1996), are ideal for identifying the species inhabiting a particular area, monitoring relative and absolute abundance of species, and studying activity patterns (Karanth, 1995; van Schaik and Griffths, 1996; Karanth and Nichols, 1998; Kawanishi et al., 1999; Koerth and Kroll, 2000; McCuUough et al., 2000; Martorello et al., 2001; O'Brien et al., 2003). Camera traps have become an indispensable tool in many wildlife studies worldwide ranging from simple documentation of animal presence to rigorous investigation of animal ecology based on quantitative, experimental and statistical inference (Sunarto et al., 2013).

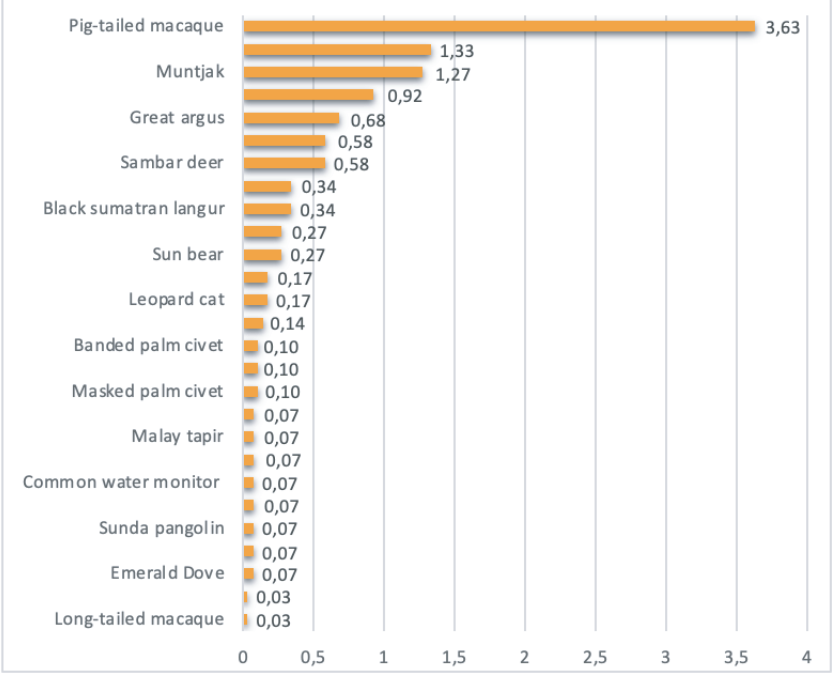

Figure 2. Relative Abundance Indices (RAI's) for each animal photograph per 100 trap days.

Based on the calculation of the relative abundance index in the two areas, the values obtained for each species, where the Pig-tailed macaque, Wild boar, and Barking deer had the highest RAI (3.63, 1.33, and 1.27 photographed/100 trap days, respectively) compared to other species. Whilst the Sumatran tiger, as the top predators in the region, placed at 18th rank with a RAI value of 0.07 . Based on trophic level (based on the type of food) which is divided into three categories i.e. herbivores, carnivores and omnivores, the relative abundance of herbivores has a high value. Therefore, the pyramid of food web will be formed properly and the balance of the ecosystem in the research location will be occurred Huda et al., (2020). This is in line with the study of Huda et al., (2020) which the Sumatran tiger in Batutegi Protected Forest, has the position of 15 th rank of RAI with a value of 0.13 , and Santosa et al., (2008) which obtained 14 species of herbivores, five species of carnivores, and three species of omnivores in Tanjung Puting National Park, Central Kalimantan.

The Pig-tailed macaque and Wild boar are the highest RAI value, because both animals are generally in large groups at one time so that when they were in front of the camera trap, each individual will be captured. In hill dipterocarp forest in West Sumatra, Pig tailed macaque had an average group size of 10.5 individuals (range $=1-20$ individuals), larger than in montane forests which had an average group size was 7 individuals (range $=6-8$ individuals), whilst in sub-montane forests the average group size was 9.5 individuals. Moreover, in lowland forest, the average group size of this macaque was 8.5 individuals (range= 1-13 individuals) being slightly smaller than in sub-montane forests and slightly larger than in the montane forests (Yanuar et al., 2009). The Wild boar is one of the most widely distributed ungulates in the world due to its high reproductive rate, adaptability, and opportunistic feeding (Herrero et al., 2006; Cuevas et al., 2010; Ballari and Barrios-García, 2014). At the same time, the wild boar is an important prey base for endangered large carnivores (Karanth and Sunquist, 1995) as well as a robust species for hunting that can relieve pressure on other wildlife species (Barrios-García and Ballari, 2012).

Based on the results of this study, the five species of felids were found in the areas, namely Leopard cat, Marbled cat, Asiatic golden cat, Sumatran clouded leopard and Sumatran tiger. As a top predator, the Felids family can be used as an umbrella species in species conservation efforts in the area of Batang Angkola Forest Area. In species conservation efforts, the determination of umbrella species is very important because when an umbrella species is protected, the effort will also be protecting the other species (Choudhury, 2013). The establishment of umbrella species is expected to minimize the need for human resources and funding that is still low to support wildlife conservation (Kiffner et al., 2015).

During the survey period, only two tiger photographs were collected (two images of the same female) were taken from 60 camera stations. Tigers have wide ranges, are difficult to detect and are elusive. The low number of tiger photos findings in Batang Angkola cannot be taken to mean that there are no more individual tigers in the forest apart from the photographed female. This is probably due to human factors, nature and equipment (camera trap). The human factor may be improper placement of the camera points. Terrain conditions that are difficult to reach due to hilly and steep ravines limited the team's 
movement in achieving the right location for the camera installation. The camera traps operated in the field were also affected by the weather. The sensor sensitivity level will decrease when the camera is in a relatively open and hot area.

Failures to detect species are common errors in surveys and are related to the detection probability of each species ( $\mathrm{Gu}$ and Swihart, 2004). The choices about where and when the camera traps will be placed can influence the sampling process. These choices can lead to biased results because species use the environment differently and researchers use different criteria to define the best sampling locations (Larrucea et al., 2007). The detection of mammals may vary depending on the animal's sex, age, social status (alpha or beta and resident or transient) and territoriality
(Larrucea et al., 2007), human pressure and the physical environment (Guil et al,. 2010). Species with large home ranges and migratory species present a particular set of challenges, because their habitat requirements often extend beyond the boundaries of protected areas (Lambeck, 1997; Caro and O'Doherty, 1999; Sanderson et al., 2001).

\section{Species Diversity, Richness, and Evenness}

The calculation of Shannon-Weiner analyses for every species on each sections of sampling areas is showed in Table 3. Based on Shannon Weiner analysis shows the level of diversity is a moderate category in both north and south sections. Level of evenness is high category in both north and south sections, and the level of species richness is moderate category in north section and high category in south section (Table 4).

Table 8. The calculation of Shannon Weiner analyses for every species on each sections of sampling areas.

\begin{tabular}{|c|c|c|c|c|c|c|c|c|}
\hline \multirow{2}{*}{ Species } & \multicolumn{4}{|c|}{ North Section } & \multicolumn{4}{|c|}{ South Section } \\
\hline & $n$ & pi & Inpi & pix $\ln p i$ & $n$ & pi & $\ln p i$ & pix $\ln p i$ \\
\hline Sumatran tiger Panthera tigris sumatrae & 2 & 0.01 & -4.38 & -0.06 & & & & \\
\hline Sumatran clouded leopard Neofelis diardii & 2 & 0.01 & -4.38 & -0.06 & & & & \\
\hline Asiatic golden cat Catopuma temminckii & 6 & 0.04 & -3.28 & -0.12 & 4 & 0.02 & -3.82 & -0.08 \\
\hline Marbled cat Pardofelis marmorata & 2 & 0.01 & -4.38 & -0.05 & 2 & 0.01 & -4.52 & -0.05 \\
\hline Leopard cat Prionailurus bengalensis & 2 & 0.01 & -4.38 & -0.05 & 3 & 0.02 & -4.11 & -0.07 \\
\hline Sun bear Helarctos malayanus & 3 & 0.02 & -3.98 & -0.07 & 5 & 0.03 & -3.60 & -0.10 \\
\hline Banded palm civet Hemigalus derbyanus & 1 & 0.01 & -5.08 & -0.03 & 2 & 0.01 & -4.52 & -0.05 \\
\hline Short-tailed mongoose Herpestes brachyurus & 2 & 0.01 & -4.38 & -0.05 & 1 & 0.01 & -5.21 & -0.03 \\
\hline Masked palm civet Paguma larvata & 1 & 0.01 & -5.08 & -0.03 & 2 & 0.01 & -4.52 & -0.05 \\
\hline Yellow-throated marten Martes flavigula & & & & & 2 & 0.01 & -4.52 & -0.05 \\
\hline $\begin{array}{l}\text { Long-tailed mongoose Herpestes } \\
\text { semitorquatus }\end{array}$ & & & & & 2 & 0.01 & -4.52 & -0.05 \\
\hline Binturong Arctictis binturong & & & & & 1 & 0.01 & -5.21 & -0.03 \\
\hline Malay Tapir Tapirus Indicus & 1 & 0.01 & -5.08 & -0.03 & 1 & 0.01 & -5.21 & -0.03 \\
\hline Sambar deer Rusa unicolor & 11 & 0.07 & -2.68 & -0.18 & 6 & 0.03 & -3.42 & -0.11 \\
\hline Wild boar Sus scrofa & 25 & 0.16 & -1.86 & -0.29 & 14 & 0.08 & -2.57 & -0.20 \\
\hline Lesser mouse deer Tragulus kanchil & 8 & 0.05 & -3.00 & -0.15 & 9 & 0.05 & -3.01 & -0.15 \\
\hline Muntjak Muntiacus muntjac & 17 & 0.11 & -2.24 & -0.24 & 20 & 0.11 & -2.21 & -0.24 \\
\hline Sumatran serow Capricornis sumatraensis & 6 & 0.04 & -3.28 & -0.12 & 2 & 0.01 & -4.52 & -0.05 \\
\hline Black sumatran langur Presbytis sumatrana & 2 & 0.01 & -4.38 & -0.05 & 8 & 0.04 & -3.13 & -0.14 \\
\hline Pig-tailed macaque Macaca nemestrina & 47 & 0.29 & -1.23 & -0.36 & 59 & 0.32 & -1.13 & -0.36 \\
\hline Long-tailed macaque Macaca fascicularis & & & & & 1 & 0.01 & -5.21 & -0.03 \\
\hline Sunda pangolin Manis javanica & 2 & 0.01 & -4.38 & -0.05 & 1 & 0.01 & -5.21 & -0.03 \\
\hline Malayan porcupine Hystrix brachyuran & 9 & 0.06 & -2.88 & -0.16 & 18 & 0.10 & -2.32 & -0.23 \\
\hline Malayan Field Rat Rattus tiomanicus & & & & & 5 & 0.03 & -3.60 & -0.10 \\
\hline Great argus Argusianus argus & 8 & 0.05 & -3.00 & -0.15 & 12 & 0.07 & -2.72 & -0.18 \\
\hline Emerald Dove Chalcophaps indica & & & & & 2 & 0.01 & -4.52 & -0.05 \\
\hline \multirow[t]{2}{*}{ Common water monitor Varanus salvator } & 2 & 0.01 & -4.38 & -0.05 & & & & \\
\hline & 159 & & & -2.40 & 182 & & & -2.45 \\
\hline
\end{tabular}


Table 4. Overall diversity, evenness, and species richness indexes

\begin{tabular}{lcc|cc|cc|cc}
\hline Site & S & N & H' & Category & J' & Category & D' & Category \\
\hline North section & 21 & 159 & 2.40 & Moderate & 0.79 & High & 3.95 & Moderate \\
South section & 24 & 182 & 2.45 & Moderate & 0.77 & High & 4.42 & High \\
\hline
\end{tabular}

$(\mathrm{S})=$ total number of species, $(\mathrm{N})=$ total number of individuals

$\left(\mathrm{D}^{\prime}\right)=$ species richness index, $\left(\mathrm{J}^{\prime}\right)=$ Evenness index and $\left(\mathrm{H}^{\prime}\right)=$ Shannon diversity

Diversity is identical to the stability of an ecosystem, where the diversity of an ecosystem is relatively high then the condition of that ecosystem tends to be stable (Odum, 1983; Fachrul, 2012). Indriyatno (2006) stated that the species diversity is high if the community is composed of many species with an abundance of the same species or almost the same species diversity, resulting in high complexity, because the interactions that occur within the community are very high.

There were critically endangered Sumatran tigers and Sunda pangolin detected in the study area, also endangered species of Malayan tapir, Clouded leopard and Sumatran black langur, shows the high richness of wildlife species in the study area.

The results of the analysis of species diversity $(\mathrm{H})$, which showed that in the northern and southern areas it were moderate (2.40 and 2.45 respectively). The level of evenness between north and south areas shows high evenness ( 0.77 and 0.79 respectively). This shows that the distribution of animal species in 60 stations is relatively evenly distributed despite different altitudes. In the results, the level of species richness between north and south shows moderate to high levels in the two areas (3.95 and 4.42 respectively). This result is quite surprising, considering that the study locations are protected and production forests, where in production forests, timber harvesting is still being done. Moreover, there is a concession of 15,000 ha which is still actively producing timber woods. This finding is very important for forest management in planning and evaluating on the implementation of production activities by considering the presence of wild animals in the area. According Maddox et al., (2007), the impact of existing concessions can be mitigated, provided that the company is prepared to set some land aside. If degraded habitats can be made to retain conservation value for certain species, the added habitat and potential connectivity between protected areas could provide key linkages and greatly increase the potential for both the maintenance of ecosystem services and conservation of wildlife. This has significant implications for many conservation and land use policies which prioritise by habitat quality.

During the field survey, the team also found threats to the wildlife habitat, in the form of land clearing by the local community for agricultural / plantation activities. The finding that threats to wildlife and their habitats still occur in the area requires special attention from
FMU. Suggested approach to reduce threats and control human disturbance include a combination of protection/law enforcement, awareness and alternative livelihood. The role of human disturbance in suppressing large mammal population has been documented, especially in Sumatra (Griffiths and Schaik, 1993; Kinnaird et al., 2003; Wibisono and Pusparini 2010). The main challenge of biodiversity conservation efforts is maintaining habitat quality and connectivity in the face of anthropogenic disturbance (Wang et al., 2014). Many protected areas are embedded within human-modified landscapes, where agriculture and urbanization have determined landscape structure and may represent major disturbances to natural ecosystems. Habitat loss and fragmentation are a major threat to biodiversity conservation in this context (Melo et al., 2013a). Maintaining a primary forest refuge for tigers is important (Linkie et al., 2008). As additional to support a primary forest refuge for tigers, forest production, and plantation areas in surrounding of the reserve should also be well managed. Conservation outside protected areas is essential if many wildlife populations and endangered species are to survive into the future. Conservation values outside protected areas have to be managed and protected. If conservation is to be effective outside protected areas, it has to be carried out and coordinated at a landscape level (Maddox et al., 2007).

\section{RECOMMENDATIONS}

Refers to the study results, based upon the findings of this survey, our observations and recommendations are as follow:

- The relatively high number of endangered and critical species illustrates the forest's contribution to conserving Sumatra's biodiversity. Nevertheless, many of the higher order taxa such as the Sumatran tiger have vast home-ranges that are highly sensitive to forest fragmentation. The utmost priority should be given to maintaining the connectivity of Batang Angkola forest and adjacent areas ecosystems including Batang Gadis National Park. To that end, it is recommended that FMU and relevant stakeholders examine how a biodiversity corridor can be established in the face of land-use change pressures. 
- Evidence of illegal and destructive activities in Batang Angkola requires increased patrol and law enforcement efforts. We recommend to support to increase of FMU's capacity both the protect the forest and to continue to improve the long-term forest management plan (Rencana Pengelolaan Hutan Jangka Panjang-RPHJP).

- The upscaling of the monitoring programme to a number of reserves is recommended, allowing population trends to be tracked across the landscape. Important to continue implement camera trapping and investigate additional sites that may benefit from this important conservation tool, within funding limitations. Implementing such a monitoring program would allow a coordinated and adaptive approach to conserving priority species and allocating resources.

- Infrastructure plans must integrate to biodiversity goals through the establishment of a Provincial Strategic Area (Kawasan Strategis Provinsi) of Batang Gadis Ecosystem which will connect both Batang Angkola Protected Forest and Batang Gadis National Park. This Strategic area will promote sustainable forest management, watershed conservation, environmental services and protection, and elevating the livelihoods of local communities.

\section{AGKNOWLEDGEMENTS}

The Conservation International Indonesia authors are grateful to the management authority of Indonesian Ministry of Environment and Forestry, Forest Management Unit X and Natural Resources Conservation Agency of North Sumatra, for granting permission to conduct the field surveys. For assisting with the data collection, we thanks to staff of management authority and MMP (Community Rangers). We thank Taronga Zoo and Unilever for support this study.

\section{REFERENGES}

Barrios-García, M.N. and Ballari, S.A. (2012). Impact of wild boar (Sus scrofa) in its introduced and native range: a review. Biol. Invas. 14: 2283-2300.

Ballari, S.A. and Barrios-García, M.N. (2014). A review of wild boar Sus scrofa diet and factors affecting food selection in native and introduced ranges. Mammal. Rev. 44: 124-134.

Caro, T. and O'Doherty, G. (1999). On the use of surrogate species in conservation biology. Conserv. Biol. 13: 805-814.
Carbone, C., Christie, S., Conforti, K., Coulson, T., Franklin, N., Ginsberg, J.R., Griffiths,M., Holden, J., Kawanishi, K., Kinnaird, M., Laidlaw, R., Lynam, A., Macdonald, D.W., Martyr, D., McDougal,C., Nath, L., O'Brien, T., Seidensticker, J., Smith, D.J.L., Sunquist, M., Tilson, R., and Shahruddin, W.N.W. (2001). The use of photographic rates to estimate densities of tigers and other cryptic mammals. Animal Conservation 4: 75-79.

Choudhury, A. (2013). The Mammals of North-East India. First ed. Gibbon Books and the Rhino Foundation for nature in NE India, Guwahati, India.

Cuevas, M.F., Novillo, A., Campos, C., Dacar, M.A., and Ojeda, R.A. (2010). Food habits and impact of rooting behaviour of the invasive wild boar, Sus scrofa, in a protected area of the Monte Desert, Argentina. J. Arid Environ. 74: 1582-1585.

Fachrul, M. (2012). Metode Sampling Bioekologi. Bumi Aksara. Jakarta.

Guil, F., Agudin, S., El-Khadir, N., Fernandez-Olalla, M., Figueredo, J., Dominguez, F.G., Garzon, P., Gonzalez, G., Munoz-Igualida, J., Oria, J., and Silvestre, F. (2010). Factors conditioning the camera-trapping efficiency for the Iberian lynx (Lynx pardinus). Eur. F. Wildl. Res. 56(4):633-640.

Gu, W. and Swihart, R.K. (2004). Absent or undetected? Effects of non-detection of species occurrence on wildlife habitat models. Biological Conservation 116: 195-203.

Griffiths, M. G. and van Schaik, C.P. (1993). Camera trapping a new tool for the study of elusive rain forest animals. Tropical Biodiversity 1: 131-135.

Hedges, S., Tyson, M.J., Sitompul, A.F., Kinnaird, M.F., Gunaryadi, D., and Aslan (2005). Distribution, status, and conservation needs of Asian elephants (Elephas maximus) in Lampung Province, Sumatra, Indonesia. Biological Conservation 124: 35-48.

Herrero, J., García-Serrano, A., Couto, S., Ortuno, V.M., and García-Gonzalez, R. (2006). Diet of wild boar Sus scrofa L. and crop damage in an intensive agroecosystem. Eur. F. Wildl. Res. 52: 245-250.

Huda, R., Istiadi, Y. and Priatna, D. (2020). Differences of terrestrial mammal species diversity between natural forest and edge forest areas in Batutegi Protected Forest, Lampung, Indonesia. Indonesian Fournal of Applied Environmental Studies 1(1): 33-39.

Indriyanto (2006). Ekologi Hutan. Bumi Aksara. Jakarta

Isnan, M.W., Subrata, D.D. and van Strien, N.J. (2006). Annual Report 2006. Bogor, Indonesia: Indonesian Rhino Conservation Program.

Karanth, U. K. and Nichols, J.D. (2002). Monitoring Tigers and Their Prey: A Manual for Researchers, Managers and Conservationists in Tropical Asia. Bangalore: Centre for Wildlife Studies. 
Karanth, K.U. and Sunquist, M.E. (1995). Prey selection by tiger, leopard and dhole in tropical forests. F. Anim. Ecol. 64: 439-450.

Karanth, K.U. (1995). Estimating tiger Panthera tigris populations from camera-trap data using capture-recapture models. Biological Conservation, 71: 333-338.

Karanth, K.U. and Nichols, J.D. (1998). Estimation of tiger densities in India using photographic captures and recaptures. Ecology, 79: 2852-2862.

Kawanishi, K., Sahak, A.M. and Sunquist, M. (1999). Preliminary analysis on abundance of large mammals at Sungai Relau, Taman Negara. Journal of Wildlife and Parks, 17: 62-82.

Kiros, S., Afework, B. and Legese, K. (2018). A preliminary study on bird diversity and abundance from Wabe fragmented forests around Gubre subcity and Wolkite town, Southwestern Ethiopia. International fournal of Avian $\mathcal{E}^{\circ}$ Wildlife Biol 3(5):333-340.

Koerth, B. H. and KroU, I.C. (2000). Bait type and timing for deer counts using cameras triggered by infrared monitors. Wildife Society Bulletin, 28: 630-635.

Kinnaird, M.F., Sanderson, E.W., O'Brien, T.G., Wibisono, H.T. and Woolmer, G. (2003) Deforestation trends in a tropical landscape and implications for endangered large mammals. Conservation Biology 17: 245-257.

Lambeck, R.J. (1997). Focal species: a multi-species umbrella for nature conservation. Conservation Biological 11: 849-856.

Larrucea, E.S., Brussard, P.F., Jaeger, M.M. and Barrett, R.H. (2007). Cameras, coyotes, and the assumption of equal detectability. F. Wildl. Manage 71(5):1682-1689

Linkie, M., Haidir, I.A., Nugroho, A. and Dinata, Y. (2008). Conserving tigers Panthera tigris in selectively logged Sumatran forests. Biological Conservation 141:2410 - 2415.

Linkie, M., Martyr, D.J., Holden, J., Yanuar, A., Hartana, A.T., Sugardjito, J. and Williams, N.L. (2003). Habitat destruction and poaching threaten the Sumatran tiger in Kerinci Seblat National Park, Sumatra. Oryx 37: 41-48.

Maddox,T., Priatna, D., Gemita, E. and Salampessy, A. (2007). The Conservation of Tigers and Other Wildlife in Oil Palm Plantations. Jambi Province, Sumatra, Indonesia (October 2007). ZSL Conservation Report No. 7 The Zoological Society of London, London.

McCuUough, D.R., Pei, K.C.I. and Wang, Y. (2000). Home range, activity patterns, and habitat relations of Reeves' muntjacs in Taiwan. Journal of Wildlife Management, 64: 430-441.

Martorello, D. A., Eason, T.H., and Pelton, M.R. (2001). A sighting technique using cameras to estimate population size of black bears. Wildlife Society Bulletin, 29: 500-567.
Margono, B. A., Turubanova, S., Zhuravieva, S., Potapov, P., Tyukavina, A., Baccini, A., Goetz, S. and Hansen, M.C. (2012). Mapping and monitoring deforestation and forest degradation in Sumatra (Indonesia) using Landsat time series data sets 1990 to 2010. Env. Res. Lett. 7: 1-16.

Melo, F.P., Arroyo-Rodríguez, V., Fahrig, L., Martinez-Ramos, M. and Tabarelli, M. (2013a). On the hope for biodiversity-friendly tropical landscapes. Trends in Ecology and Evolution. 28: 462-468.

Newbold, T., Hudson, L.N., Hill, S.L.L., Contu, S., Lysenko, I., Senior, R.A., Bennet, D.J. and Purvis, A. (2015). Global effects of land use on local terrestrial biodiversity. Nature 520:45-50.

O’Brien T.G, Kinnaird, M.F. and Wibisono, H.T. (2003). Crouching tigers, hidden prey: Sumatran tiger and prey populations in a tropical forest landscape. Animal Conservation 6: 131-139.

Odum, E.P (1983) Basic Ecology. CBS College Publishing, New York.

Perbatakusuma, E.A., Supriatna, J., Wijayanto, I.H., Soedijito, H., Damanik, A., Azmi, K., Arif, M.C.F. and Lubis, A.H. (2010). Strengthening Biodiversity Conservation at Key Landscape Areas in Northern Sumatra Biodiversity Corridor. [Project Report]. Conservation International Indonesia.

Santosa Y., Ramadhan, E.P., and Rahman, D.A. (2008). Studi keanekaragaman mamalia pada beberapa tipe habitat di Stasiun Penelitian Pondok Ambung Taman Nasional Tanjung Puting, Kalimantan Tengah. Media Konservasi 13(3):1-7.

Sanderson, E., Redford, K.H., Vedder,A., Coppolillo, P., and Ward, S. (2001). A conceptual model for conservation planning based on landscape species requirements. Landsc. Urban Plann. 58: 41-56.

Shafer, G. L. (1999). US national park buffer zones: Historical, scientific, social, and legal aspects. Environmental Management 23(1): 49-73.

Shannon C.E.E. (1948). A Mathematical Theory of Communication. Bell System Technical Journal 27(3): 379-423. DOI: 10.1002/j.1538-7305.1948.tb01338.x

Sodhi, N.S., Koh, L.P., Brook, B.W. and Ng, P.K.L. (2004). Southeast Asian biodiversity: an impending disaster. Trends Ecol. Evol. 19:654-660.

Stibig, H.J., Achard, F., Carboni, S., Raši, R. and Miettinen, J. (2014). Change in tropical forest cover of Southeast Asia from 1990 to 2010. Biogeosciences, 11: 247-258. doi:10.5194/bg-11-247-2014.

Sunarto S., Sollmann, R., Mohamed, A. and Kelly, M.J. (2013). Camera trapping for the study and conservation of tropical carnivores. The Raffles Bulletin of Zoology 28:21-42. 
Van Schaik, C. P. and Griffiths, M. (1996). Activity periods of Indonesian rain forest mammals. Biotropica 28: 105-1 12.

Wibisono, H.T. and Pusparini, W. (2010). Sumatran tiger (Panthera tigris sumatrae): A review of conservation status. Integr. Zool. 5: 313-323.

Wang, F., McShea, W., Wang, D., Li, S., Zhao,Q., Wang, H. and Lu, Z. (2014). Evaluating Landscape Options for Corridor Restoration between Giant Panda Reserves. PLoS One 9(8): 1-10.

Wemmer, G., Kunz, T.H., Lundie-Jenkins, G. and McShea, W.J. (1996). Mammalian sign. In: Wilson, D. E., F. R. Cole, J. D. Nichols, R. Rudran and M. S. Foster (eds.). Measuring and Monitoring Biological Diversity. Standard Methods for Mammals. Pp. 157- 176. Smithsonian Institution Press, Washington and London.
Whitten, T., Damanik, S.J., Anwar, J., and Hisyam, N. (2000). The Ecology of Sumatra. 2nd edition. Periplus Editions, Singapore.

Wikramanayake, E.D., Dinerstein, E., Loucks, G.J., Olson, D.M., Morrison, J., and Lamoreux, J. (2002). Terrestrial Ecoregions of the Indo-Pacific: A Conservation Assessment. Island Press, Washington, DC.

Yanuar A., Chivers, D.J., Sugardjito, J., Martyr, D.J., and Holden, J.H. (2009). The Population Distribution of Pig-tailed macaque (Macaca nemestrina) and long-tailed macaque (Macaca fascicularis) in West Central Sumatra, Indonesia. Asian Primates fournal 1(2):2-11.

Appendix 1. Selection of animals photographs taken by camera traps during 2020 survey, Batang Angkola.Landscape.
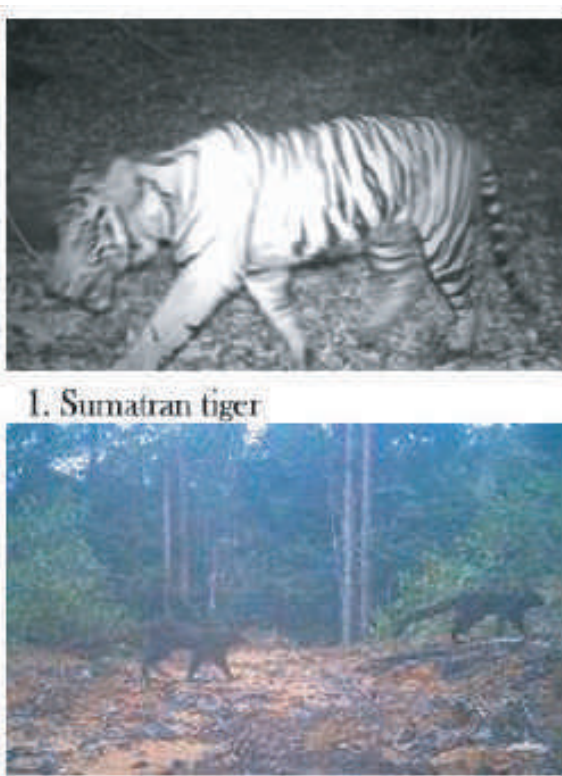

4. Marbled cat

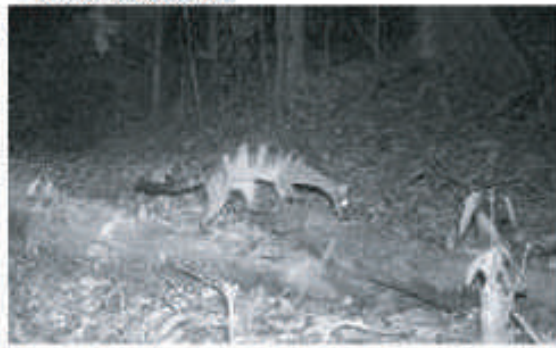

7. Banded palm civet

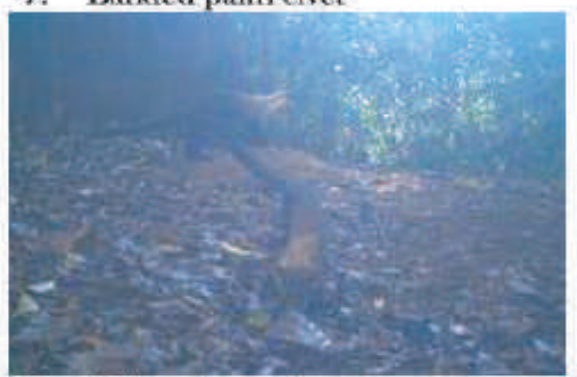

10. Yellow-throated marten

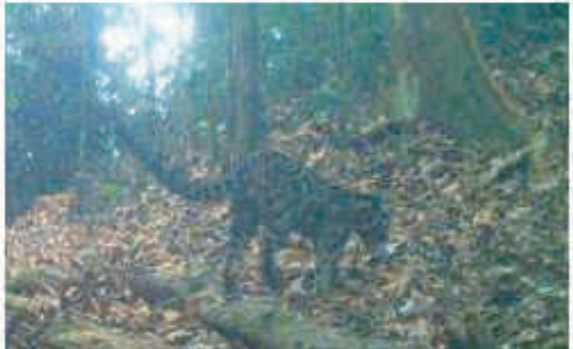

2. Sumatran clouded leopard

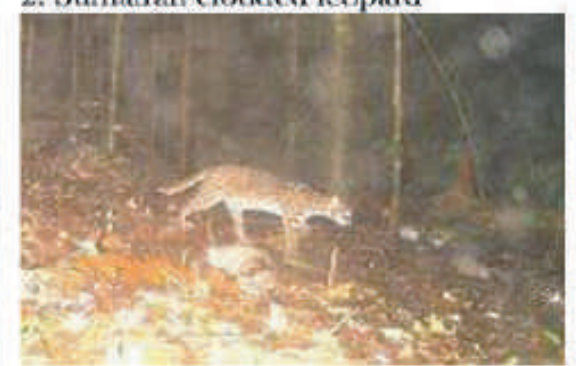

5. Leopard cat

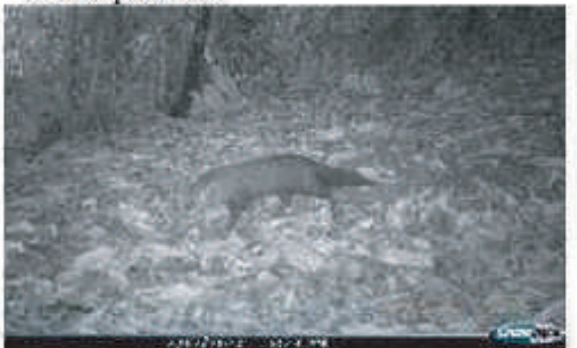

8. Short-tailed mongoose

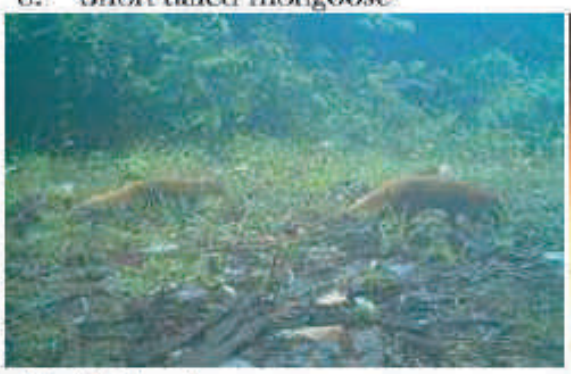

11. Collared mongoose

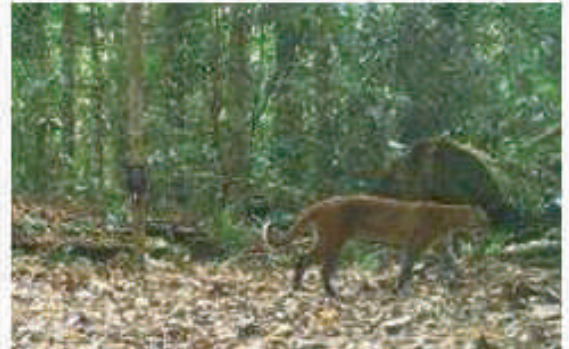

3. Asiatic golden cat

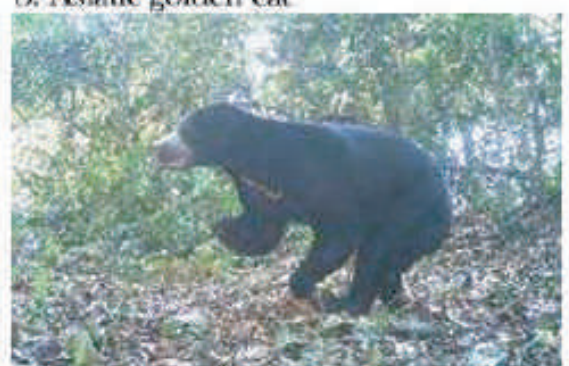

6. Sun bear

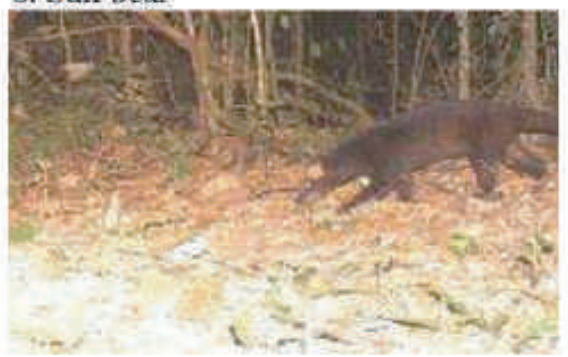

9. Masked palm civet

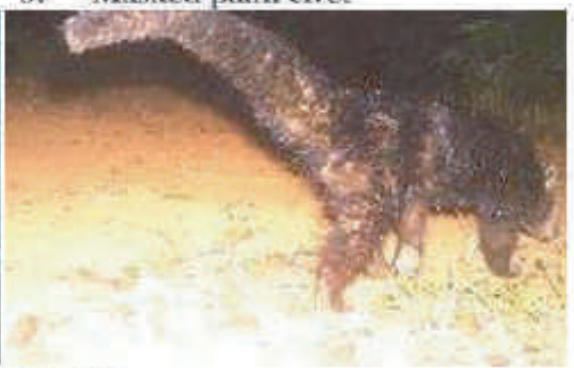

12. Binturong 


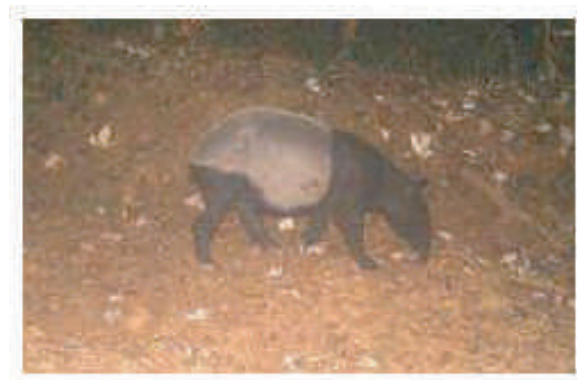

13. Malay tapir
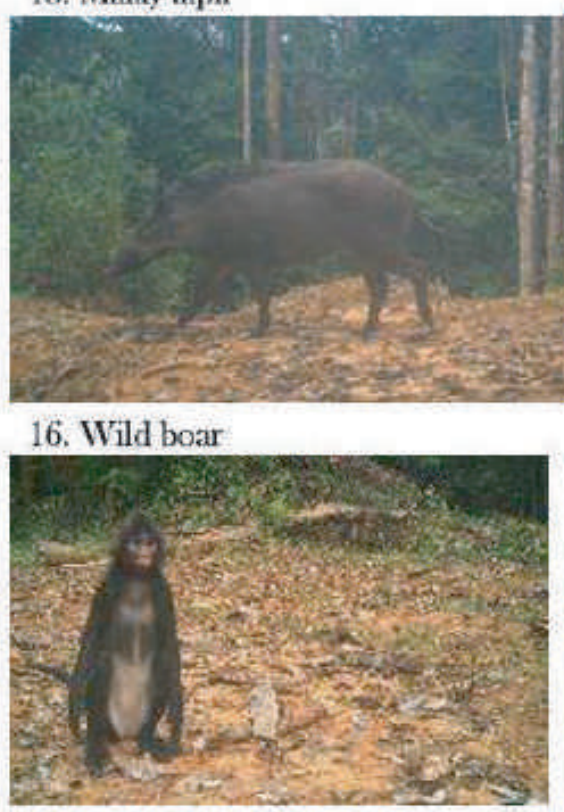

19. Black sumatran langur

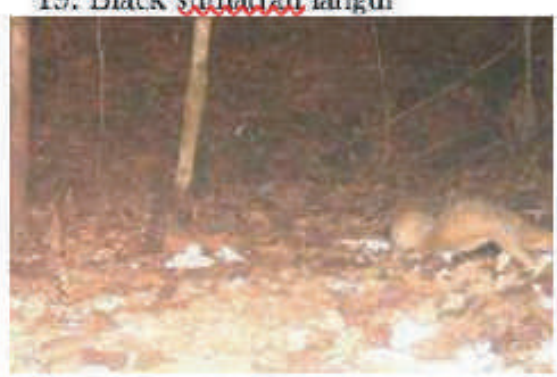

22. Sunda pangolin

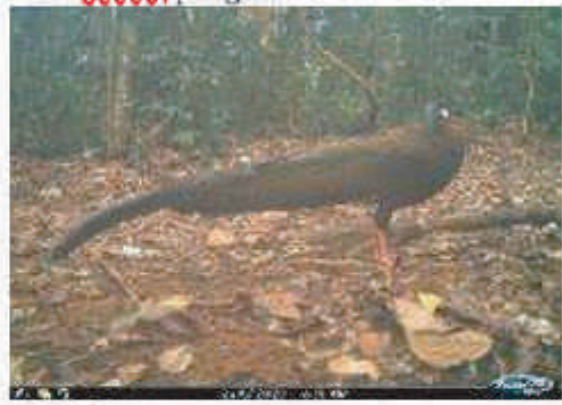

25. Great argus

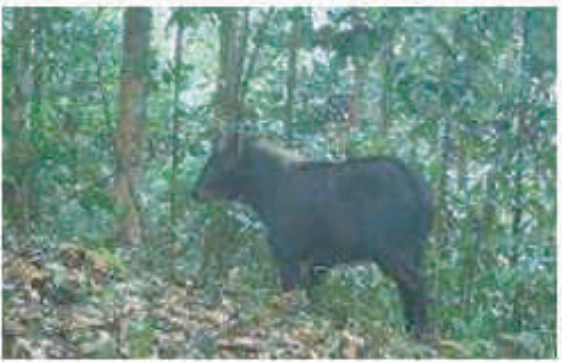

14. Sumatran scrow

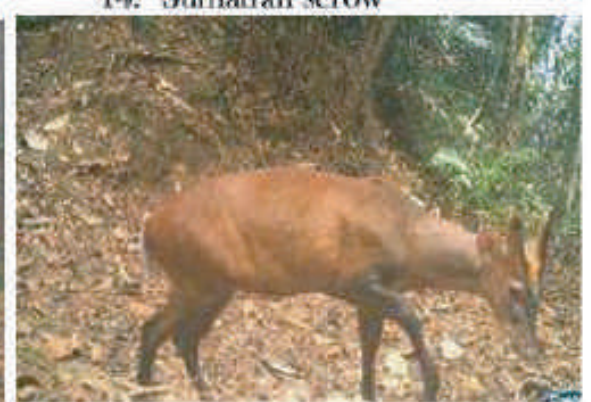

17. Muntigk

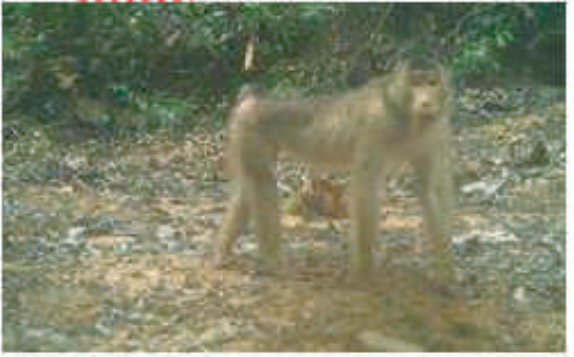

20. Pig-tailed macaque

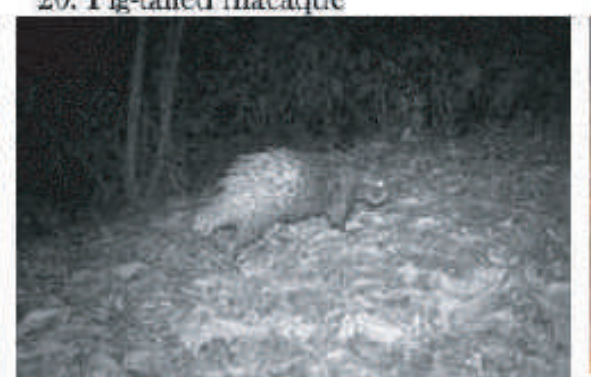

23. Malayan porcupine

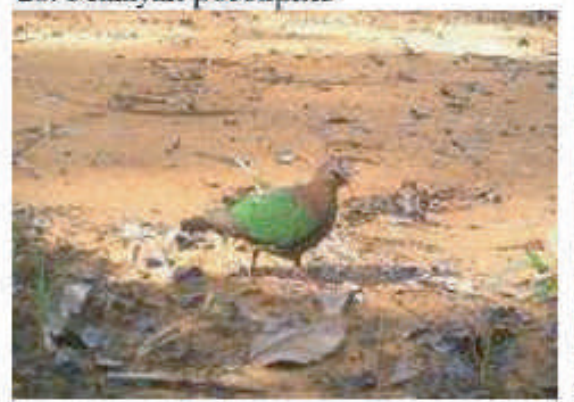

25. Emerald dove

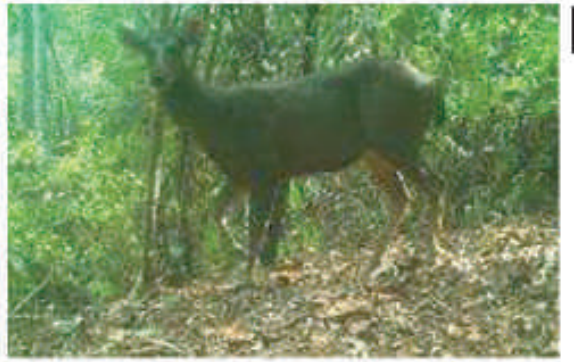

15. Sambar deer

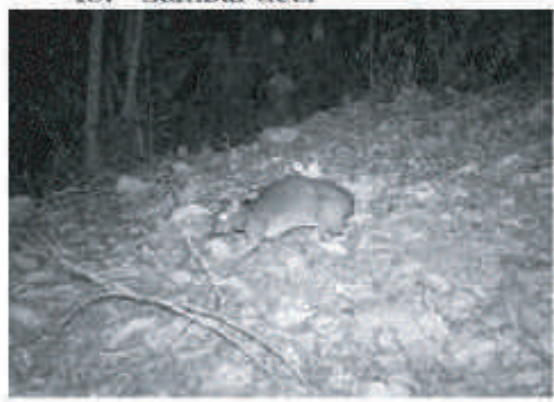

18. Lesser mouse deer

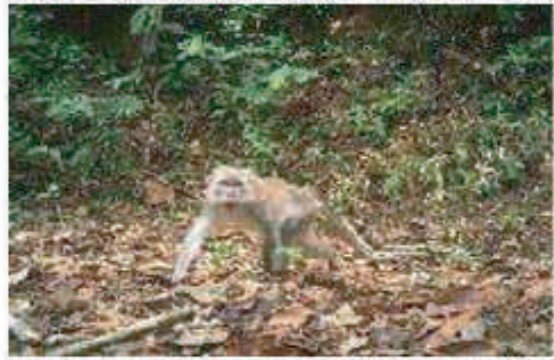

21. Long-tailed macaque

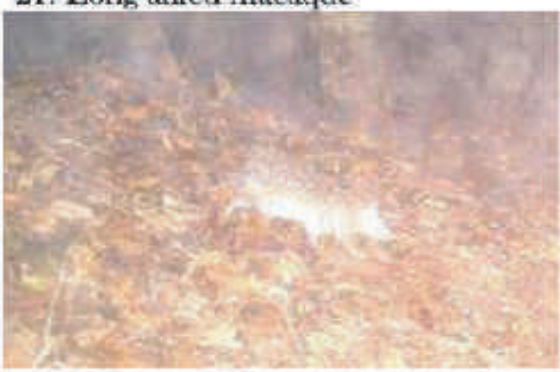

24. Malayan field rat

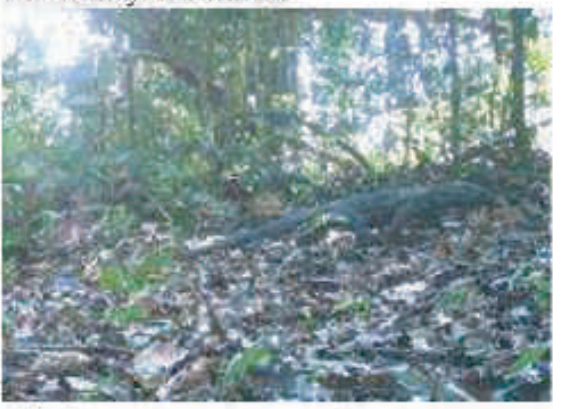

27. Common water monitor 